Service quality and servicescape of the restaurants in Las Piñas City

Dinero, Baddie M., Jr. $\bowtie$

Batangas State University JPLPC - Malvar, Philippines (baddie.dinero@gmail.com)

Apritado, Jennie Margaret M.

Lyceum of the Philippines University Batangas, Philippines (jmapritado@lpubatangas.edu.ph)

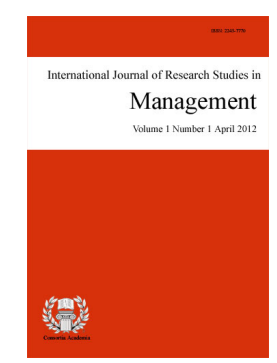

ISSN: $2243-7770$ Online ISSN: 2243-7789

\title{
Abstract
}

This study assessed the service quality and servicescape of the restaurants in Las Piñas City. Specifically, it assessed the service quality of the casual dining restaurants; determined the servicescape of the restaurant; tested the significance difference when grouped according to the profile variables. This study used descriptive method of research', the data were collected from 403 using the availability sampling. The adapted questionnaire was distributed using the online Google Form. On the other hand, Mann-Whitney Test was used to determine the significant difference when grouped according to the profile variables. The researcher ensured that data privacy of the respondents was secured. Based from the result, the service quality of the restaurants is relatively strong on the aspect of tangible, followed by assurance and satisfaction, reliability, responsiveness, empathy and price respectively. On the other hand, the qualification of the staff and service presentation is highly regarded by the respondents, followed by physical environment (internal presentation) and product/brochures/menus/webpage, Interior and Exterior Ambient Conditions, physical environment (external presentation) and direct/indirect external servicescape respectively. The study concluded that Majority of the respondents are at the age of 23 to 38 years of age or generation Y, female, single, college graduate and employed as part timer.

Keywords: service quality, servicescape of the restaurant, casual dining 


\section{Service quality and servicescape of the restaurants in Las Piñas City}

\section{Introduction}

A restaurant, like any other business, necessitates a well-thought-out business strategy. Various concepts are used in the restaurant industry. It covers all areas of the business, including the target demographic, the establishment's design, customer service, and, most significantly, the cuisine that will be offered. Restaurants should have a pleasant environment, delicious food that caters to a wide range of consumers, a well-designed dining room, and staff with a pleasant demeanor. When dining in a restaurant, the food's quality and the physical surroundings have an impact on the client. According to Du (2017), there are many different types of restaurant concepts; nonetheless, the concept of a restaurant must be established and understood because it acts as the foundation for the remainder of your business plan. Many other aspects of the development of your restaurant's operation, such as the restaurant's idea will influence the type of cuisine, the type of service, the menu design, the price, the size and seating capacity, the furnishing style, and the operation hours.

A full-service restaurant serves casual eating. It has a relaxed and comfortable atmosphere. The casual dining menu is extremely inexpensive and fits into any budget. The menu's design and the ambiance entice families to dine in. A family-style restaurant that serves a full-course meal can also be classified as a casual dining establishment. A family-style restaurant is a casual dining establishment where patrons can relax in the dining room while receiving meals on a platter. The concept of casual dining is served in a family-oriented restaurant with table service, non-disposable dishes, reasonable prices, classic cuisines with featured dishes and some customized sauces and decorations, and cozier and inviting décor and environment (Du, 2017). Family-style dining, according to Mealy (2018), is when customers help themselves to the cuisine, which is served on platters (just like at home). Many traditional Chinese and Korean restaurants provide this style of dining. Quality alone is not a full measure of how restaurant guests or customers react to their waiters' activities, but a distinct style of service delivery on a dimension other than quality is also a component in determining customer contentment in a certain restaurant (Giebelhausen et al., 2016).

With the changes to the infrastructure, the restaurant should focus on innovation as well. They must be knowledgeable about current trends, cooking styles, service, and design. To boost their bottom line, the majority of eateries are increasingly innovating. Implementing innovation, according to (Lee et al., 2016), can boost restaurant performance. New food items and service systems, as well as marketing innovations such as the use of social networking sites to promote the business and customer loyalty programs, are examples of restaurant innovations (Ivkov et al., 2018). Innovation aid in market survival, process and product improvement, and business idea upgrading.

The entire world was just confronted with the most fatal illness, COVID-19. People from all over the world were affected by the disaster. COVID-19 has killed 571,199 people and infected nearly 32 million people in the United States since January, according to (Hernandez et al., 2021). According to an Associated Press investigation (AP, 2021), Europe has now had 1 million COVID-19 deaths, and the situation remains "serious," with around 1.6 million new cases reported every week in the region. In the Philippines, the COVID-19 issue has gotten worse.

Since the beginning of April, the country has averaged more than 10,400 daily COVID-19 cases, approximately double the amount in March and much higher than the 213 per day in April 2020 and 2,169 in the second half of last year, according to health ministry data. Not only were people's lives impacted, but so were businesses, particularly in the hospitality industry. Due to a lack of revenue, some eateries had to close (Grindy, 2020). Restaurants, on the other hand, are putting up a strong fight. Because so many people's lives are on the line, there's a lot of life in it. Even if it was simply for the sake of their staff, several firms have remained open. 
According to (Taylor, 2020), the ability to reopen for eating here service was a welcome shift for restaurateurs; but, because worries about safety and social alienation remained, many restauranteurs had to get inventive in guaranteeing guest and worker safety. Most restaurants in Metro Manila have installed a temperature scanner to monitor the temperature of their patrons, as well as a disinfection matting before entering the premises.

SERVQUAL is a multidimensional research tool that evaluates the factors that determine the quality of restaurant service. Five dimensions are used to assess service quality. This covers both tangibles and satisfaction, such as dependability, responsiveness, assurance, empathy, and price. The importance of service quality in maintaining the company's development capability has been identified. The SERVQUAL scale is the most used tool for assessing service quality in today's service business, according to (Hu et al., 2017).

One of the most critical issues that every organization encounter is providing high-quality service to clients (Namin, 2017). The Servicescape model was created to demonstrate the importance of the actual setting in which the service is provided. A better perception of the servicescape, according to Cautela Tvrzská de Gouvêa et al., (2020), helps to the establishment of a pleasant attitude toward revisiting a restaurant. A positive assessment of an environment in terms of its spatial layout, signs, and symbols generates pleasant feelings and memories, as well as aids in the formation of good opinions.

The goal of the servicescapes model is to explain people's behavior in service settings so those surroundings can be constructed that do not accomplish corporate goals in terms of behavioral reactions. (Lap-kwong, 2017), Customer satisfaction and service quality have long been seen as key considerations in achieving competitive market success. Customer service is a crucial factor of every establishment. It covers the majority of the procedures. The most significant aspect of marketing quality that determines restaurant quality and loyalty is people (Kukanja et al., 2016). The restaurant's service should be in keeping with the ambiance, design, and cuisine. Together with the restaurant's facilities, customer service is the restaurant's face. For best customer satisfaction, restaurants must plan, implement, evaluate, and improve on many elements of service operations on a regular and continual basis (Limakrisna \& Ali, 2016). In Metro Manila, there are several eateries, particularly in the city Las Piñas. The majority of them are restaurants with a relaxed atmosphere. Due to the Asian ex-pats that reside among the natives, they serve a range of cuisines, some of which are Filipino in origin and others which are Asian in origin. To build on the problems generated by the study's findings, the researcher is inspired to analyze service quality and servicescape. As a result, restaurateurs will be better aware of how to improve their business by offering superior service, affecting customer satisfaction and retention in the foodservice industry. The overall goal and hypothesis must be stated. It also discusses the study's implications for the intended community and profession's practice, as well as its contribution to the discipline.

\subsection{Objectives of the study}

This study assessed the service quality and servicescape of the restaurants in Metro Manila. Specifically, 1) it presented the demographic profile of the respondent in terms of age, sex, civil status, educational background and occupation; 2) assessed the service quality of the casual dining restaurants in terms of: tangible, reliability, responsiveness, assurance, empathy, price and satisfaction; 3) determined the SERVICESCAPE of the restaurant in terms of physical environment (external presentation and internal presentation), qualification of the staff and service presentation, interior and exterior ambient conditions, product / brochure / menu / webpage, and direct / indirect external service influence; 4) tested the significance difference in the assessment of service quality in terms of tangible, reliability, responsiveness, assurance, empathy, price and satisfaction, and servicescape in terms of physical environment (external presentation and internal presentation), qualification of the staff and service presentation, interior and exterior ambient conditions, product / brochure / menu / webpage, and direct / indirect external service influence when grouped according to the profile variables. 


\section{Methods}

Research Design - The purpose of this research was to see if there was a link between restaurant service quality, servicescape, customer service, and facility innovation in Metro Manila, specifically in Las Piñas City. The descriptive technique was used in this study to collect and classify the data to demonstrate the relevance of the association between the respondents' profile and the restaurant's service quality and Servicescape. According to McCombes (2020), descriptive research aims to accurately and systematically describe a population, condition, or phenomenon. A descriptive research plan might use a variety of research approaches to investigate one or more variables.

Participants of the Research - Customers from a selected casual dining restaurant in Las Piñas took part in the survey. There were five (5) casual dining restaurants that have been opened for three years. A total of 403 people were requested to participate in the data gathering. $G^{*}$ Power 3.1.9 was used to calculate the sample size. The effect size of the detected number of participants is 0.25 , with a power probability of 0.95 and an alpha level of 0.05. The google form was used to sample the participants. For distribution, the researcher used Facebook Messenger and enlisted the help of friends and relatives to circulate the questionnaire to others who had dined at the selected restaurants. The participants in the study were divided into four groups: those under the age of 22 and below (Generation Z), those between the ages of 23 and 28, (Generation Y), 39-54 (Generation X), and 55 and up (Generation X) (Baby Boomers).

Instrument - For measuring the SERVQUAL and the SERVICESCAPE of the restaurants, this study employed a modified questionnaire from the studies of Marković et al. (2011), Nguyen et al. (2018), and Turker et al. (2018). The study instrument had been validated by the researcher's advisers. A pilot test was done to determine the research instrument's reliability. The thirteen variables' Cronbach's coefficients are over 0.8 and substantially higher than 0.7 , exceeding the stated requirement. Furthermore, the item-total correlations of all variables are greater than 0.8 , with the lowest being 0.834 and the greatest being 0.953 . As a result, the variables meet all of the criteria for analysis reliability. The demographics of the responder are covered in the first section of the questionnaire. The second half will evaluate the casual dining restaurant's service quality in terms of tangibles such as reliability, responsiveness, assurance, empathy, price, and satisfaction. The third step is to determine the restaurant's Servicescape, which includes the physical environment (both external and internal presentation), staff qualification and service presentation, interior and exterior ambient conditions, products/brochure/menu/webpage, and direct and indirect external Servicescape.

Data Gathering Procedures - Before the researcher was granted permission to perform this study by the Dean of the Graduate School of the Lyceum of the Philippines - Batangas, the research instrument had gone through various procedures and revisions to comply with modern food and beverage industry standards. Following approval, the researcher used Google Forms and Facebook Messenger to disseminate the questionnaire to his family, relatives, and friends, as well as other persons associated with his family, relatives, and friends who had dined at the restaurants that are part of this study. Even though the questionnaires were sent online, the data collection took a week.

Data Analysis - To evaluate the data, the data was encoded in Microsoft Excel and processed via SPSS ver.16. Frequencies and percentages were used to report categorical variables. The mean and median were presented for both continuous and ordinal variables. The Mann-Whitney test was used to assess the significant difference when the SERVQUAL and the SERVICESCAPE of the restaurants were grouped by profile.

Ethical Considerations - The respondents were given plenty of time to react to the question by the researcher. The respondent was treated with the utmost respect. Before the study, the respondents gave their full consent. Respondents and organizations that took part in the study were kept anonymous. 


\section{Results and Discussion}

The percentage distribution of the respondents' profiles is shown in Table 1. In terms of age, the majority between the ages of 23 and 38 belong to generation Y, with 182 or 45.20 percent; 39 to 54 years old belong to generation X, with 99 or 24.60 percent; 22 years of age and below belong to generation Z, with 96 or 23.80 percent; and 55 years and above have the least number of 26 or 6.50 percent. The statistics suggest that the majority of individuals dining during the pandemic are from generation $y$, meaning those between the ages of 23 and 28. Generation x, or those between the ages of 39 and 54, are the next in line. Baby Boomers, who are 55 and older, have the lowest income. Also, those in generation $\mathrm{Z}$ are 22 years old or younger.

\section{Table 1}

Percentage distribution of the respondents' profile

\begin{tabular}{|c|c|c|}
\hline Age & Frequency & Percentage $(\%)$ \\
\hline 22yrs old and below (Generation Z) & 96 & 23.80 \\
\hline 23-38yrs old (Generation Y) & 182 & 45.20 \\
\hline 39-54yrs old (Generation X) & 99 & 24.60 \\
\hline $55 y r s$ old and above (Baby Boomers) & 26 & 6.50 \\
\hline \multicolumn{3}{|l|}{ Sex } \\
\hline Male & 153 & 38.00 \\
\hline Female & 250 & 62.00 \\
\hline \multicolumn{3}{|l|}{ Civil Status } \\
\hline Single & 225 & 55.80 \\
\hline Married & 171 & 42.40 \\
\hline Widow/Widower & 7 & 1.70 \\
\hline \multicolumn{3}{|l|}{$\begin{array}{ll}\text { Educational Attainment } \\
\end{array}$} \\
\hline High School & 11 & 2.70 \\
\hline College & 318 & 78.90 \\
\hline Post Graduate & 62 & 15.40 \\
\hline Others & 12 & 3.00 \\
\hline \multicolumn{3}{|l|}{$\begin{array}{l}\text { Occupation } \\
\end{array}$} \\
\hline Employed Full time & 245 & 60.80 \\
\hline Employed Part-time & 30 & 7.40 \\
\hline Seeking Opportunities & 55 & 13.60 \\
\hline Retired & 9 & 2.20 \\
\hline Prefer not to say & 64 & 15.90 \\
\hline
\end{tabular}

Since the Inter-Agency Task Force for the Management of Emerging Infectious Diseases, or IATF, announced their rules and regulations, it appears that people aged 55 and over, as well as those aged 22 and up, are still adhering to the rules and regulations. According to the IATF (2020), as stated in their Omnibus Rules on Community Quarantine with Amendments, section 3 number 3 of their guidelines. Anyone under the age of fifteen (15), those over sixty-five, those with immunodeficiency, comorbidity, or other health risks, and pregnant women, as well as anyone who lives with them, are required to stay in their homes at all times, except when necessary for obtaining essential goods and services, or for work (As amended by paragraph A of IATF Resolution No. 79, dated October 15, 2020.) Meanwhile, female respondents account for 250 (or 62.00 percent) of the total population, while male respondents account for 153 (or 38.00 percent). Our population is reported to have a higher proportion of females than males. The findings even suggest that women are primarily responsible for purchasing food for personal consumption or the provision of meals to their families. According to the tabulated census of (DOH, 2020), the number of people aged 5 to 65 in Las Piñas City is 576, 531, with males numbering 283,459 and females numbering 293,072.

The majority of respondents are single (225, or 55.80 percent); married (172, or 42.40 percent); and widow/widower (172, or 42.40 percent) in terms of civil status ( 7 , or 1.70 percent). The findings suggest that majority of single respondents prefer to go outside. It's also reasonable to suppose that they spend more time dining alone in restaurants, mingling with their friends, than they do remain at home or eat with their families. The breakfasting commuter, the household members with clashing schedules: eating alone has become a distinguishing characteristic of modern life (Fleming, 2019). A married couple spends most of their time at home 
and has responsibilities to their family. Instead of dining out, some people prefer to spend time and eat with their families at home rather than in public settings. The government also claims that just a small number of people are allowed to dine in.

When it comes to respondents' educational attainment, the majority (318 or 78.70 percent) are college graduates, followed by postgraduate degrees (62 or 15.40 percent), other (12 or 3.00 percent), and high school graduates (11 or 2.70 percent). Because we are in the midst of a pandemic, students and younger kids are not permitted to leave the residence. Furthermore, a large portion of the respondents are employed full time, accounting for 245 or $60.80 \%$; followed by these preferring not to say, accounting for 63 or 15.60 percent; seeking opportunities, accounting for 55 or 13.60 percent; employed part, accounting for 30 or 7.40 percent; and retired part, accounting for 9 or 2.20 percent.

In terms of occupations, the majority of the participants work full-time to support their families. Following that, they either prefer not to say or are simply working on a project-based structure. The next step is to look for opportunities. This is someone who has recently graduated from school or is currently unemployed. Another is part-time employed. Most employees nowadays are hired on a part-time basis, and some of them may even be students. They must work to support themselves during their studies. The least is the no longer employed. These are the people who are not working but receive a pension to help them meet their necessities.

The unemployment rate in January 2021 remained steady from $8.7 \%$ in October 2020, according to PSA. This is the lowest rate since April 2020, but it is higher than the January 2020 figure of 5.3 percent. However, the employment rate in January 2021 was 91.3 percent, the same as in October 2020. This means that out of a total workforce of 45.2 million Filipinos, 41.2 million were working in January 2021. This projection falls short of the 94.7 percent predicted in January 2020. 2021) (PSA). Furthermore, according to the PSA (2021) study, in January 2021, 6.6 million underemployed or employed people reported a wish for greater hours of work in their current job, a second job, or a new job with long hours of work, accounting for $16.0 \%$ of the total employed population. This rate of underemployment is greater than the $14.4 \%$ rate in October 2020 and the 14.8 percent rate in January 2020.

Table 2

Assessment on the Service Quality of the Restaurants

\begin{tabular}{lcccc}
\hline \multicolumn{1}{c}{ Indicators } & Cronbach Alpha & Weighted Mean & Verbal Interpretation & Rank \\
\hline Tangible & 0.908 & 3.53 & Strongly Agree & 1 \\
Reliability & 0.906 & 3.42 & Agree & 4 \\
Responsiveness & 0.843 & 3.39 & Agree & 5 \\
Assurance & 0.898 & 3.45 & Agree & 2.5 \\
Empathy & 0.949 & 3.32 & Agree & 6 \\
Price & 0.834 & 2.56 & Agree & 7 \\
Satisfaction & 0.910 & 3.45 & Agree & 2.5 \\
\multicolumn{1}{c}{ Composite Mean } & & 3.30 & Agree & \\
\hline
\end{tabular}

Legend: $3.50-4.00=$ Strongly Agree; $2.50-3.49=$ Agree $1.50-2.49=$ Disagree $; 1.00-1.49=$ Strongly Disagree.

Table 2 shows the summary table on the service quality of the restaurants with the composite mean of 3.30 verbally interpreted as agree. Based on the result among the variables, tangible (3.53) is the topmost and strongly agreed by the respondents; followed by assurance and satisfaction (3.45) and reliability (3.42) as agreed. According to survey respondents, the restaurant was clean, well-maintained, and sanitized. Given that we are in the midst of a pandemic, respondents asked restaurants to adhere to government requirements such as social distance, chairs and tables segregated from one another, and a one-meter gap between clients. The restaurants' responders indicate that they are secure. They wanted the eateries to help the staff as well. When it comes to service, the staff informs customers about the menus and how they are prepared. The employees are also at ease and confident while working, and they can provide thorough answers to questions. The respondents are also satisfied with the excellent quality of service, the respondents have also expressed that they will return to the store and recommend the restaurants to others. According to Omar, et.al (2016), tangibles are the appearance of an establishment's physical facilities, equipment, and employees; restaurants use tangibles to represent their 
image and signal quality to customers.

The rest of the variables are agreed by the respondents that the restaurant is responsive (3.39); and empathize (3.32) and the price turned the least among the sub-variables (2.56). Staff members are putting in extra effort to handle specific requests, according to the respondents. During busy periods, staff-maintained speed and quality of service, and they are courteous. The respondents also reveal that the staff gives the customer's best interests at heart; they are sympathetic and reassuring employees, employees provide individual attention, staffs anticipate customer's individual needs and wants and they give a special feeling to the customers. In many cases, pricing is the most important element to consider while purchasing food or other things. It has always been a determining factor in decision-making and a push factor in the acquisition. According to Amirudin (2013), pricing is the most influential factor in determining the relationship between service quality and price, and consequently has the greatest impact on customer loyalty. It was also shown that reduced consumer fares increase the likelihood of increased customer loyalty. Because service quality is a process carried out by all personnel in the organization, determining customer expectations is the most critical condition for boosting service quality (Wu \& Cheng, 2013). Many aspects of the quality of the service that customers purchase is evaluated and interpreted by customers from their perspectives. In other words, they compare the expected and perceived quality of service (Uslu, 2020).

Table 3

Assessment on the servicescape of the restaurants

\begin{tabular}{lccll}
\hline \multicolumn{1}{c}{ Indicators } & Cronbach Alpha & WM & VI & Rank \\
\hline Physical Environment: External Presentation & 0.953 & 3.51 & Strongly Agree & 5 \\
Physical Environment: Internal Presentation & 0.947 & 3.54 & Strongly Agree & 2.5 \\
Qualifications of the staff and Service Presentation & 0.92 & 3.57 & Strongly Agree & 1 \\
Physical Environment: Internal Presentation & 0.936 & 3.53 & Strongly Agree & 4 \\
Product/ Brochures/ Menus/ Webpage & 0.95 & 3.54 & Strongly Agree & 2.5 \\
Direct/ Indirect External Servicescape & 0.938 & 3.50 & Strongly Agree & 6 \\
\multicolumn{1}{c}{ Composite Mean } & & 3.53 & Strongly Agree & \\
\hline
\end{tabular}

Legend: 3.50 - 4.00 = Strongly Agree; 2.50 - 3.49 = Agree; 1.50 - 2.49 = Disagree ; $1.00-1.49=$ Strongly Disagree.

Table 3 shows the summary table on the servicescape of the restaurants with the composite mean of 3.53 as strongly agree. The qualifications of the staff and service presentation (3.57) is the topmost among the variable, followed by physical environment: internal presentation and product/ brochures/ menus/ webpage (3.54); and Interior and Exterior Ambient Conditions (3.53). All indicators are strongly agreed upon by the respondents. Qualification of the staff and service presentation is very important in the servicescape of the restaurant. The restaurant should be disinfected all the time, table and chairs should be arranged after use so that when the next customer arrives the place is presentable and clean. Since the restaurant is presentable and clean this one goes also with the staff. Staff must be well-groomed all the time. They represent the image of the restaurant. Housekeeping of the restaurant should always be observed. Keeping the area clean and tidy is important. Most of the people are observing the cleanliness of the store. Now that we are in the pandemic, the restaurant should a good handwashing facility and they must provide hand sanitizer and it should always be visible in the restaurant. It must be placed near the entrance, counter, and in some part of the dining area. Restrooms must be clean, with plenty of soap and toilet paper, as well as a drying facility. The Internal presentation of the restaurant must be attractive with distinctive qualities that differentiate it from other restaurants. It should also have an excellent spatial layout and the designs of the interior are conforming to high quality. Contactless payment should be practice in the restaurant. Since we are in the world of technology. Restaurants must adapt to the technology. It is a good sign that they evolve to stay in touch with the customers. The brochure should be well-designed so that it is easy to read, and the food and beverage should be in keeping with the restaurant's image. The design of the webpage should be easy to navigate for the customers can use it very well.

In addition, the physical environment: external presentation (3.51) and direct/ indirect external servicescape (3.50) are also strongly agreed by the respondents. The number of customers coming into the restaurant must be restricted to avoid the spread of the virus among customers. This was also implemented by the government for 
Dinero, B. M., Jr., \& Apritado, J. M. M.

the safety of the people. The exterior, layout, and landscape must give an impression to the customer. The restaurant should also have a temperature in the entrance to monitor the temperature of the guest. This has been practicing by all establishments since it is mandated by the government. Signage on the building must be seen clearly by the customer. The signage must be well place in front of the building. It stands as the landmark of the restaurant. The Exterior glass window must be clean so that the restaurant must look presentable from the outside view. The scenery must keep with the restaurant design and brand image it gives the customer a pleasant look with the restaurant. Information about the restaurant must be indicated in the information in the brochure. This gives the customer a background about the restaurant. Maps must be easily read to avoid the problem to the customer regarding the location.

Based on the study of Turker et al. (2019), customers were pleased with the service staff, and there were no problems with the service. The exterior canopy and shelters of the restaurant were well-sheltered and also aesthetically pleasing. The restaurant's design is in keeping with the surrounding environment, and the music complements the atmosphere. The restaurant has a pleasant odor and is peaceful and comfortable. Nonetheless, customers were pleased with the uniforms, personal grooming, and restaurant service quality. Additionally, the interior temperature/air quality, as well as the food and beverages available at the restaurants, received high marks.

Table 4

Difference of responses on the service quality of the restaurants when grouped according to profile

\begin{tabular}{|c|c|c|c|}
\hline Age & $\mathrm{U} / \lambda^{2}{ }_{\mathrm{c}}$ & $\mathrm{p}$-value & Interpretation \\
\hline Tangible & 3.268 & 0.352 & Not Significant \\
\hline Reliability & 1.609 & 0.657 & Not Significant \\
\hline Responsiveness & 2.023 & 0.568 & Not Significant \\
\hline Assurance & 3.847 & 0.278 & Not Significant \\
\hline Empathy & 5.828 & 0.120 & Not Significant \\
\hline Price & 17.973 & 0.000 & Highly Significant \\
\hline Satisfaction & 4.358 & 0.225 & Not Significant \\
\hline \multicolumn{4}{|r|}{ 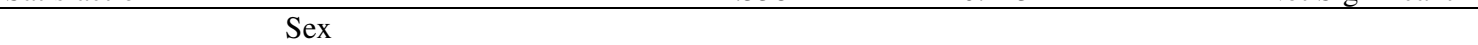 } \\
\hline Tangible & 19072.5 & 0.963 & Not Significant \\
\hline Reliability & 17660.5 & 0.188 & Not Significant \\
\hline Responsiveness & 17275 & 0.088 & Not Significant \\
\hline Assurance & 18487 & 0.564 & Not Significant \\
\hline Empathy & 17483 & 0.138 & Not Significant \\
\hline Price & 17812.5 & 0.229 & Not Significant \\
\hline Satisfaction & 18598.5 & 0.628 & Not Significant \\
\hline \multicolumn{4}{|c|}{ Civil Status } \\
\hline Tangible & 0.219 & 0.896 & Not Significant \\
\hline Reliability & 0.774 & 0.679 & Not Significant \\
\hline Responsiveness & 2.455 & 0.293 & Not Significant \\
\hline Assurance & 0.854 & 0.652 & Not Significant \\
\hline Empathy & 2.23 & 0.328 & Not Significant \\
\hline Price & 11.605 & 0.003 & Significant \\
\hline Satisfaction & 0.204 & 0.903 & Not Significant \\
\hline \multicolumn{4}{|c|}{ Educational Attainment } \\
\hline Tangible & 1.068 & 0.785 & Not Significant \\
\hline Reliability & 1.814 & 0.612 & Not Significant \\
\hline Responsiveness & 1.558 & 0.669 & Not Significant \\
\hline Assurance & 1.632 & 0.652 & Not Significant \\
\hline Empathy & 0.242 & 0.971 & Not Significant \\
\hline Price & 1.542 & 0.673 & Not Significant \\
\hline Satisfaction & 1.114 & 0.774 & Not Significant \\
\hline \multicolumn{4}{|c|}{ Occupation } \\
\hline Tangible & 2.278 & 0.685 & Not Significant \\
\hline Reliability & 1.795 & 0.773 & Not Significant \\
\hline Responsiveness & 1.583 & 0.812 & Not Significant \\
\hline Assurance & 1.339 & 0.855 & Not Significant \\
\hline Empathy & 0.463 & 0.977 & Not Significant \\
\hline Price & 10.147 & 0.038 & Significant \\
\hline Satisfaction & 0.971 & 0.914 & Not Significant \\
\hline
\end{tabular}

26 Consortia Academia Publishing (A Partner of Tourism Educators and Movers of the Philippines) 
Table 4 displays the comparison of responses on the service quality of restaurants. When comparing prices by age $(p=0.000)$, civil status $(p=0.003)$, and occupation $(p=0.038)$, it was discovered that there was a substantial difference in pricing. This was noticed because the resultant p-values were less than the 0.05 alpha level, indicating that the replies were statistically different. According to the results of the post hoc test, respondents aged 22 and under (Generation $\mathrm{Z}$ ), who are married and work part-time, have a higher opinion of pricing.

The aged 22 years old and below are most dependent on their parents. They just rely on their allowances, therefore, the price of the food in the restaurant matters to them. For those persons whose age is 22 years old and below, most of them are only studying and relying upon their allowance. That is why they have agreed that the food item is expensive and they paid more than their expected price for the food. An expensive price can have an impact on customer satisfaction the disparities in all parameters of service quality the older clients have higher expectations and perceptions of all service quality parameters than younger customers, which is to be expected given their higher income. (Spyridou, 2017) According to the study of Zhong and Moon (2020), one of the important findings was that quality dimensions of a restaurant and the perceived price had positive effects on customer satisfaction. Moreover, they found that a reasonable price could positively and directly affect customers' perceptions toward the quality of a restaurant.

Most like similar to the married respondents, the price of the food matters to them. This group of respondents is very particular with their budgeting in the family. They usually do not intend to spend more their planned. Married couples must budget their expenses because they have a lot to pay, such as house rent, a stipend for going to work, and support for their family. That is why they do not have to pay exorbitant prices for their food. According to Namin (2017)'s research, restaurants can change the prices of their items. They can provide different food sizes at different price points for different target customers. They can also offer lower unit prices for larger purchases. Another suggestion would be to offer a variety of "combo" menus, which will have a lower price compared to the sum of the prices of all items included, to provide more value to their customers. And for those working part-timers, they also value their money since their work is not stable and not earning that much compared to those full-time workers or employees. Hence, employees who temporarily value their money. This type of employee-only receives a basic salary and cannot afford to buy expensive food daily. They must save or allocate their money for other expenses such as rent, bills, and allowance when they go to work because they are only temporarily employed.

The majority of respondents, particularly those aged 22 and under, as well as married couples, and working part-timer place a high value on money. Restaurants must lower their prices so that customers can afford to eat at their establishments. Combination menus are an excellent example of cost-cutting. Combo menus are increasingly popular in restaurants these days. According to Abdullah's (2018)'s research, the majority of customers were satisfied with the service quality provided by restaurateurs. The study also discovered that price fairness has a significant relationship with customer satisfaction. From the study of Namin (2017), he adds that in a competitive market, another strategy would be to keep an eye on the prices offered by the other market players and maintain a competitive pricing strategy. These strategies can assist a restaurant in improving its price-value ratio and achieving higher levels of customer satisfaction, which will eventually result in better behavioral intentions and greater market success. One of the most vulnerable aspects of a product is its price. When a product's price is high, the product's quality is also high. However, if companies raise their prices without improving their quality, customer satisfaction will suffer, implying that price has an impact on customer satisfaction (Cristo et al., 2017).

Table 5 compares responses on servicescape from a specified restaurant when they are categorized by profile variables. Because the resulting p-values were less than 0.05 alpha level, there was a significant difference in staff qualification and service presentation $(p=0.006)$, product/brochures/menus/webpage $(p=0.036)$, and direct/indirect external servicescape $(p=0.032)$ when grouped by age. This indicates that the replies differ 
Dinero, B. M., Jr., \& Apritado, J. M. M.

statistically, and a pairwise comparison revealed that people aged 22 and under (Generation Z) have higher ratings on the above-mentioned variables.

Table 5

Difference of responses on the servicescape of the restaurants when grouped according to profile

\begin{tabular}{|c|c|c|c|}
\hline $\begin{array}{l}\text { Age } \\
\end{array}$ & $\mathrm{U} / \lambda^{2} \mathrm{c}$ & p-value & Interpretation \\
\hline Physical Environment: External Presentation & 6.621 & 0.085 & Not Significant \\
\hline Physical Environment: Internal Presentation & 7.498 & 0.058 & Not Significant \\
\hline Qualifications of the staff and Service Presentation & 12.445 & 0.006 & Significant \\
\hline Interior and Exterior Ambient Conditions & 7.307 & 0.063 & Not Significant \\
\hline Product/ Brochures/ Menus/ Webpage & 8.541 & 0.036 & Significant \\
\hline Direct/ Indirect External Servicescape & 8.785 & 0.032 & Significant \\
\hline \multicolumn{4}{|l|}{ Sex } \\
\hline Physical Environment: External Presentation & 18690.5 & 0.699 & Not Significant \\
\hline Physical Environment: Internal Presentation & 18493 & 0.569 & Not Significant \\
\hline Qualifications of the staff and Service Presentation & 19114.5 & 0.992 & Not Significant \\
\hline Physical Environment: Internal Presentation & 18852 & 0.804 & Not Significant \\
\hline Product/ Brochures/ Menus/ Webpage & 18720.5 & 0.707 & Not Significant \\
\hline Direct/ Indirect External Servicescape & 18465.5 & 0.528 & Not Significant \\
\hline \multicolumn{4}{|l|}{ Civil Status } \\
\hline Physical Environment: External Presentation & 4.607 & 0.100 & Not Significant \\
\hline Physical Environment: Internal Presentation & 2.857 & 0.240 & Not Significant \\
\hline Qualifications of the staff and Service Presentation & 8.577 & 0.014 & Significant \\
\hline Interior and Exterior Ambient Conditions & 7.336 & 0.026 & Significant \\
\hline Product/ Brochures/ Menus/ Webpage & 5.63 & 0.060 & Not Significant \\
\hline Direct/Indirect External Servicescape & 3.707 & 0.157 & Not Significant \\
\hline \multicolumn{4}{|l|}{$\begin{array}{ll}\text { Educational Attainment } \\
\end{array}$} \\
\hline Physical Environment: External Presentation & 5.651 & 0.130 & Not Significant \\
\hline Physical Environment: Internal Presentation & 3.335 & 0.343 & Not Significant \\
\hline Qualifications of the staff and Service Presentation & 5.44 & 0.142 & Not Significant \\
\hline Interior and Exterior Ambient Conditions & 5.672 & 0.129 & Not Significant \\
\hline Product/ Brochures/ Menus/ Webpage & 6.503 & 0.090 & Not Significant \\
\hline Direct/ Indirect External Servicescape & 7.163 & 0.067 & Not Significant \\
\hline \multicolumn{4}{|l|}{$\begin{array}{ll}\text { Occupation } \\
\end{array}$} \\
\hline Physical Environment: External Presentation & 2.389 & 0.665 & Not Significant \\
\hline Physical Environment: Internal Presentation & 6.229 & 0.183 & Not Significant \\
\hline Qualifications of the staff and Service Presentation & 7.858 & 0.097 & Not Significant \\
\hline Interior and Exterior Ambient Conditions & 9.5 & 0.050 & Not Significant \\
\hline Product/ Brochures/ Menus/ Webpage & 4.893 & 0.298 & Not Significant \\
\hline Direct/Indirect External Servicescape & 7.604 & 0.107 & Not Significant \\
\hline
\end{tabular}

Legend: Significant at $\mathrm{p}$-value $<0.05$.

Respondents tend to look at the staff the way how they carry themselves, how they manage the conversation with the customers and they serve or handle the food. Especially, those in the age of 22 years old and below. These respondents aged 22 and under are keenly aware of the qualifications of the staff and how they serve. The restaurant must take action. Staff training on how to deal with customers could be beneficial. When categorized by civil status, there was also a significant difference in personnel qualification, service presentation, and interior and exterior ambient conditions because the p-values were less than the alpha level. As a result, the replies differ significantly, and a post hoc test revealed that married respondents place a higher value on the qualifications of the employees, service presentation, and internal and external ambient conditions. It states that it is necessary to encourage employees to report and assess their performance every week, as well as the restaurant manager to keep track of their performance to have directions to improve the restaurant's service quality (Ngoc \& Uyen, 2015).

Respondents would tend to observe how these staffs are qualified for their job. In this case, they are looking into how the staff performs the job. The quality of service given to them is important to them. Moreover, they are meticulous on the service presentation and physical environment of the restaurant. They usually check on how food is being served, handled and how the queries are answered. The ambiance of the place is important to them especially when they are with their children or the whole family. According to the research of Ngoc and Uyen (2015), it is critical to develop an appropriate program and to provide ongoing training on the various aspects

28 Consortia Academia Publishing (A Partner of Tourism Educators and Movers of the Philippines) 
that guests are concerned about. Such as: serving skills, speeding up check settlement, knowledge about foods, beverages, and wines served in restaurants, experience, understanding guests' specific needs, and being attentive to strengthening employee ability and improving service quality as well as product quality of luxury restaurants.

\section{Conclusion}

The majority of the respondents are between the ages of 23 and 38, or generation Y, female, single, college graduates, and full-time employees. Based on the results among the sub-variables of service quality, tangible is the topmost and strongly agreed by the respondents followed by assurance and reliability as agreed. The respondents also pointed to responsiveness and empathy as agreed. However, the price was marked as agree but the least among the sub-variables. Based on the results, among the sub-variables of servicescape, qualifications of the staff and service presentation are highly favored by the respondents followed by the physical environment in terms of internal presentation and product/brochures/menus/webpage then interior and exterior ambient condition and physical environment in terms of external presentation. The least is direct/indirect external servicescape. All sub-variables are strongly agreed upon by the respondents. Based on the results of the service quality survey, that the opinions of 22-year-old respondents differed on restaurant price and servicescape. The married ones, on the other hand, have different perspectives on price and the inside and external climatic circumstances. Furthermore, those who work part-time have differing opinions on price alone. Except for pricing, there is a considerable association between restaurant service quality and service escape.

Based on the findings, it was recommended for Owners, managers, and staff of the restaurant, they may all share responsibilities for ensuring that guests are handled professionally. The restaurant may utilize a customer service checklist to verify if it meets the highest restaurant service standards and always provides an exceptional guest experience. When hiring and training staff members, restaurant management may emphasize skills such as empathy, patience, and the ability to respond quickly when interacting with clients. Restaurant management may develop and promote corporate culture by teaching staff how to follow a set of etiquette norms and how to handle challenging situations. Having restaurant service standards in place makes it easier for the team to provide consistent service. A future researcher could do a similar study with different factors, such as customer service training and interpersonal skills training.

\section{References}

Abdullah, D., Hamir, N., Nor, N. M., Krishnaswamy, J., \& Rostum, A. M. M. (2018). Food quality, service quality, price fairness, and restaurant re-patronage intention: The mediating role of customer satisfaction. International Journal of Academic Research in Business and Social Sciences, 8(17), 211-226. https://doi.org/10.6007/IJARBSS/v8-i17/5226

Amirudin, N. H. (2013). Price, service quality and customer loyalty: A case of Air Asia. Southeast Asia Journal of Contemporary Business, Economics, and Law, 2(1) 2289-1560.

Associated Press. (2021, April 15) U.S. News “WHO: Has Surpassed 1 Million Covid-19 Deaths. Retrieved from, https://www.usnews.com/news/world/articles/2021-04-15/who-europe-has-surpassed-1-million-covid-1 9-deaths

Cautela Tvrzská de Gouvêa, A. B., Kyoko Wada, E., \& Gonçalves Oliveira, P. S. (2020). Themed restaurants and hospitality: What do young people think? Journal of Hospitality, 2(3-4), 72-82.

Cristo, M., Saerang, D. P. E., \& Worang, F. G. (2017). The influence of price, service quality, and physical environment on customer satisfaction. Case study Markobar Cafe Mando Pengaruh Harga. Journal Emba.,5(2), 678-686.

Department of Health. (2020, August 27). Age-specific population projection, 2020, NCR.pdf. Retrieve from https://doh.gov.ph/

Du, P. (2017). The business plan of Izakaya restaurant in Helsinki. [Master's, Thesis, Vaasan Ammattikorkeakoulu University of Applied Sciences]. Business Economics and Tourism. Retrieve from, 
Dinero, B. M., Jr., \& Apritado, J. M. M.

https://www.theseus.fi/

Fleming, A. (2019, May 6). The guardian. Table for one: How eating alone is radically changing our diets. Retrieve from https://www.theguardian.com/

Giebelhausen, M., Chan, E., \& Sirianni, N. J. (2016). Fitting restaurant service style to brand image for greater customer satisfaction. Cornell Hospitality Report, 16(9), 3-10. https://core.ac.uk

Grindy, B. (2020). National restaurant association; restaurant sales and job losses are widespread across segments. https://restaurant.org/articles/news/restaurant-sales-and-job-loses-are-widespread

Ivkov, M., Blešić, I., Simat, K., Demirović, D., \& Božić, S. (2018). Innovations in the restaurant industry: An exploratory study. Economics of Agriculture, 63(4), 1169-1186. https://doi.org/10.5937/ekoPolj1604169I

Kukanja, M., Gomezelj Omerzel, D., \& Kodrič, B. (2016). Ensuring restaurant quality and guests' loyalty: An integrative model based on marketing (7p) approach. Total Quality Management \& Business Excellence, 28(13-14), 1509-1525. https://doi.org/10.1080/14783363.2016.1150172

Lap-Kwong, D. (2017). The role of servicescape in hotel buffet restaurant. Journal of Hotel Business Management, 6(152). https://doi.org/10.4172/2169-0286.1000152

Limakrisna, N., \& Ali, H. (2016). Model of customer satisfaction: Empirical study at fast food restaurants in Bandung. International Journal of Business and Commerce, 5(6). 132-146.

Marković, S., Raspor, S., \& Dorčić, J. (2011). What are the key dimensions of restaurant service quality? An empirical study in the city restaurant settings. Sustainable Tourism: Socio-Cultural, Environmental and Economic Impact, 235-249.

McCombes. S. (2020). Descriptive research. Retrieve from https://www.scribbr.com

Namin, A. (2017). Revisiting customers' perception of service quality in fast food restaurants. Journal of Retailing and Consumer Services, 34, 70-81. https://doi.org/10.1016/j.jretconser.2016.09.008

Ngoc, K. M. \& Uyen, T. T. (2015, December). Factors affecting guest perceived service quality, product quality, and satisfaction- A study of luxury restaurants in Ho Chi Minh City, Vietnam. Journal of Advanced Management Science, 3(4).

Nguyen, Q., Nisar, T. M., Knox, D., \& Prabhakar, G. P. (2018). Understanding customer satisfaction in the UK quick-service restaurant industry. British Food Journal, 120(6),

1207-1222. https://doi.org/10.1108/bfj-08-2017-0449

Omar, M. S., Ariffin, H. F., \& Ahmad, R. (2016). Service quality, customers' satisfaction and the moderating effects of gender: A study of Arabic restaurants. Procedia - Social and Behavioral Sciences, 224. 384-392. https://doi.org/10.1016/j.sbspro.2016.05.393

Philippine Statistics Authority. (2021, March 9). Employment Situation in January 2021. Retrieve from, https://psa.gov.ph/

Spyridou, A. (2017). Perceived service quality and customer revisiting intention: The case of "all you can eat" asian restaurants in southern Taiwan. Journal of Tourism, Heritage \& Services Marketing, 3(2), 30-38. https://doi.org/10.5281/zenodo.1209129

Taylor, S., Jr. (2020). The socially distant servicescape: An investigation of consumer preference's during the re-opening phase. International journal of hospitality management, 91, 102692.

https://doi.org/10.1016/j.ijhm.2020.102692

Türker, N., Gökkaya, S., \& Ayşegül, A. C. A. R. (2019). Measuring the effect of restaurant servicescapes on customer loyalty. Turizm Akademik Dergisi, 6(2), 255-270.

Uslu, A. (2020). The relationship of service quality dimensions of restaurant enterprises with satisfaction, behavioural intention, ewom, and the moderating effect of atmosphere. Tourism \& Management Studies, 16(3), 23-35 https://doi.org/10.18089/tms.2020.160303

Wu, H. C., \& Cheng, C. C. (2013). A hierarchical model of service quality in the airline industry. Journal of Hospitality and Tourism Management, 20, 13-22. https://doi.org/10.1016/j.jhtm.2013.05.001

Zhong, Y., \& Moon, H. C. (2020). What drives customer satisfaction, loyalty, and happiness in fast-food restaurants in China? Perceived price, service quality, food quality, physical environment quality, and the moderating role of gender. Foods, 9(4), 460. https://doi.org/10.3390/foods9040460

30 Consortia Academia Publishing (A Partner of Tourism Educators and Movers of the Philippines) 
Service quality and servicescape of the restaurants in Las Piñas City

\section{Appendix. Questionnaire}

Part I. Assess the service quality of the restaurants.

Direction: Please tick or check each item based on the scale. 4 - Strongly Agree 3 - Agree 2 - Disagree 1 - Strongly Disagree

\begin{tabular}{|c|c|c|c|c|}
\hline Tangibles & 4 & 3 & 2 & 1 \\
\hline 1. Visually attractive parking areas and building exteriors & & & & \\
\hline 2. Visually attractive dining area & & & & \\
\hline $\begin{array}{l}\text { 3. Clean, and appropriately dressed staff; wearing face mask and shield, maintaining physical distancing in dealing with } \\
\text { customers }\end{array}$ & & & & \\
\hline 4. Restaurant's décor typical of its image and price range & & & & \\
\hline 5. Visually attractive menu & & & & \\
\hline 6. Clean, properly maintained, and sanitized restrooms & & & & \\
\hline 7. Clean dining areas with visible color-coded markings on the floor to guide the participants & & & & \\
\hline 8. Comfortable dining areas with space relative to the social distancing & & & & \\
\hline 9. Chairs and tables set apart of at least 1 meter between guests and one another & & & & \\
\hline 10. Comfortable and sanitized seats in the dining room & & & & \\
\hline 11. Specific number of customers accommodated in the restaurant (limited to $50 \%$ of the maximum venue capacity) & & & & \\
\hline Reliability & 4 & 3 & 2 & 1 \\
\hline 1. Service at the promised time & & & & \\
\hline 2. Dependable and consistent restaurant & & & & \\
\hline 3. Quick corrections of wrong service & & & & \\
\hline 4. Accurate bill & & & & \\
\hline 5. Error-free served order (food) & & & & \\
\hline Responsiveness & 4 & 3 & 2 & 1 \\
\hline 1. Maintaining speed and quality of service during busy times & & & & \\
\hline 2. Provisions of Prompt service & & & & \\
\hline 3. Extra effort for handling special requests & & & & \\
\hline Assurance & 4 & 3 & 2 & 1 \\
\hline 1. The employees can answer questions completely. & & & & \\
\hline 2. The staff provides a comfortable and confident feeling. & & & & \\
\hline 3. the staff provide information about menu items, their ingredients, and method of preparation & & & & \\
\hline 4. The customers are feeling safe & & & & \\
\hline 5. The staffs are well trained, competent and experienced. & & & & \\
\hline 6. The restaurant supports the employees. & & & & \\
\hline Empathy & 4 & 3 & 2 & 1 \\
\hline 1. The employees provide individual attention to the customer. & & & & \\
\hline 2. The staff provides a special feeling to their customer. & & & & \\
\hline 3. The staff anticipates customers' individual needs and wants. & & & & \\
\hline 4. The staff are sympathetic and reassure customers' needs and wants. & & & & \\
\hline 5. The staff makes sure that customers' best interests are at heart. & & & & \\
\hline $\begin{array}{rr} & \text { Price } \\
\end{array}$ & 4 & 3 & 2 & 1 \\
\hline 1. Expensive food item & & & & \\
\hline 2. Paying more than planned & & & & \\
\hline Satisfaction & 4 & 3 & 2 & 1 \\
\hline 1. Overall satisfaction with dining experience & & & & \\
\hline 2. Returning to the restaurant & & & & \\
\hline 3. Recommending the restaurant to others & & & & \\
\hline 4. Excellent quality of service & & & & \\
\hline
\end{tabular}


Dinero, B. M., Jr., \& Apritado, J. M. M.

Part II. Determine the Servicescape of the restaurants

Direction: Please tick or check each item based on the scale. 4 - Strongly Agree 3 - Agree 2 - Disagree 1 - Strongly Disagree

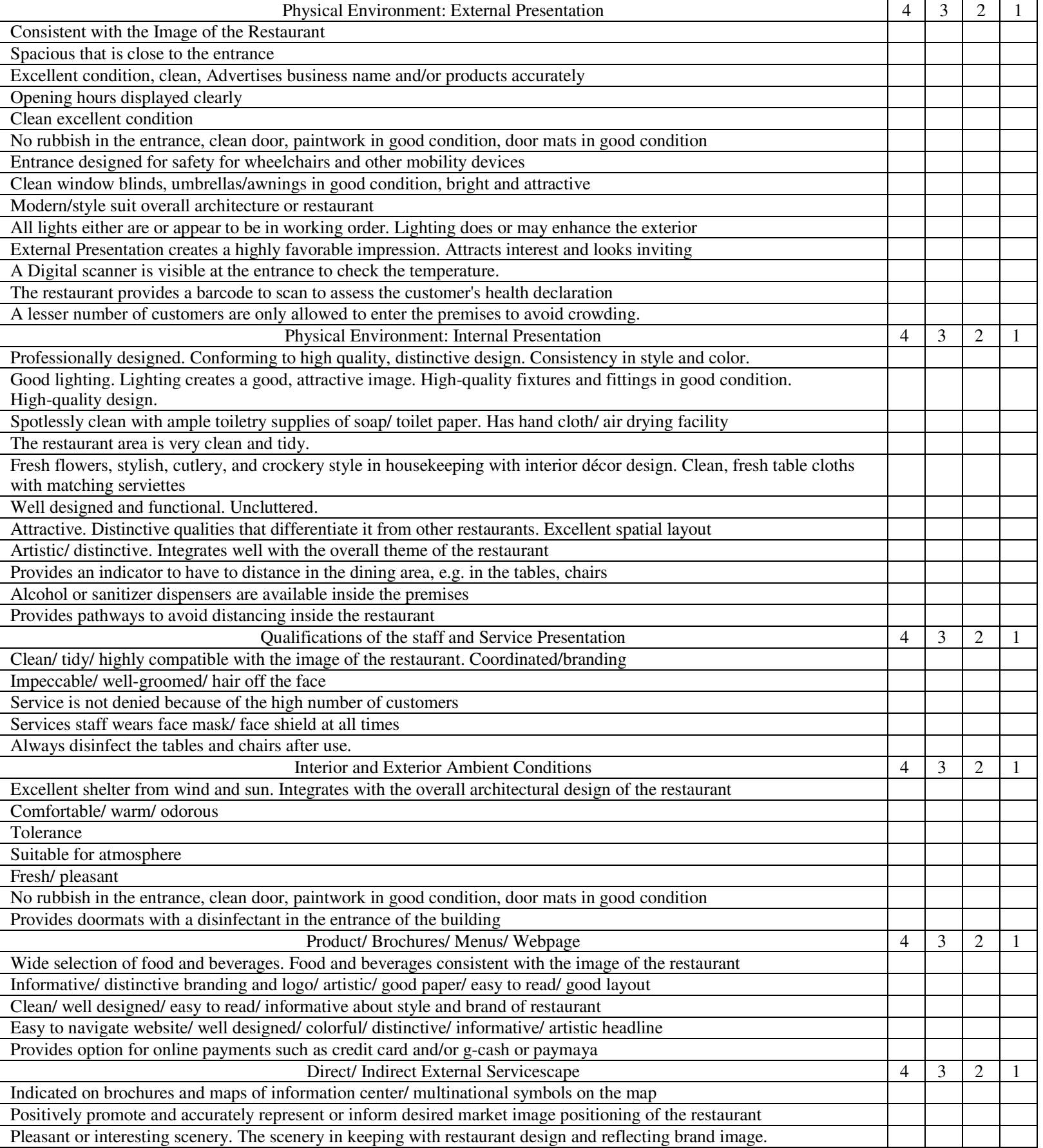

